\title{
Occasional Motes
}

REPORT OF THE CONFERENGE OF THE PROGRAMME-EXEGUTIVE COMMITTEE OF THE SEGOND INTERNATIONAL NEUROLOGIGAL GONGRESS, LONDON, 1935

Held at the Royal Society of Medicine, London, September 6 and 7, 1933

I. The Programme Conference was attended by the following Delegates :

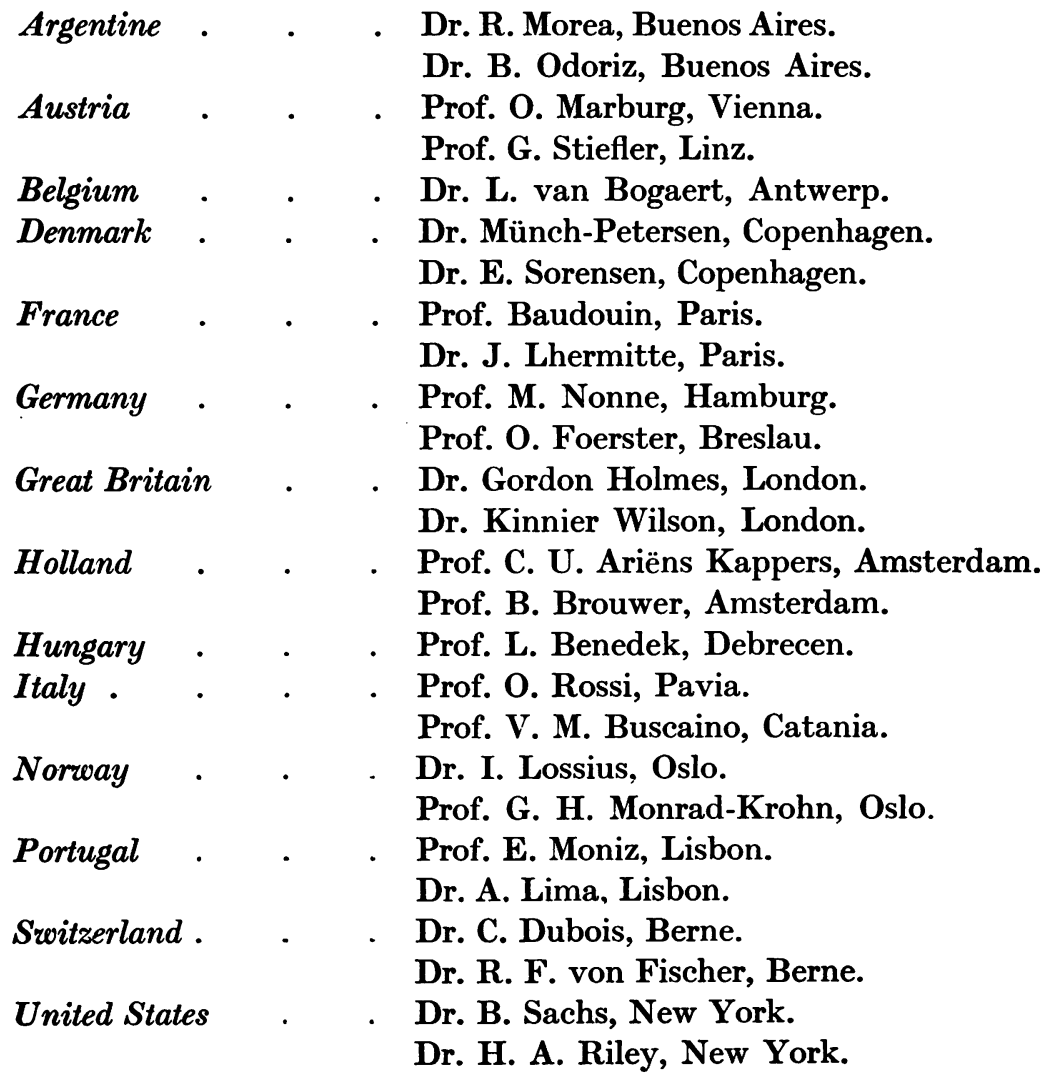


Letters expressing regret for their inability to attend the Conference were received from the following Delegates :

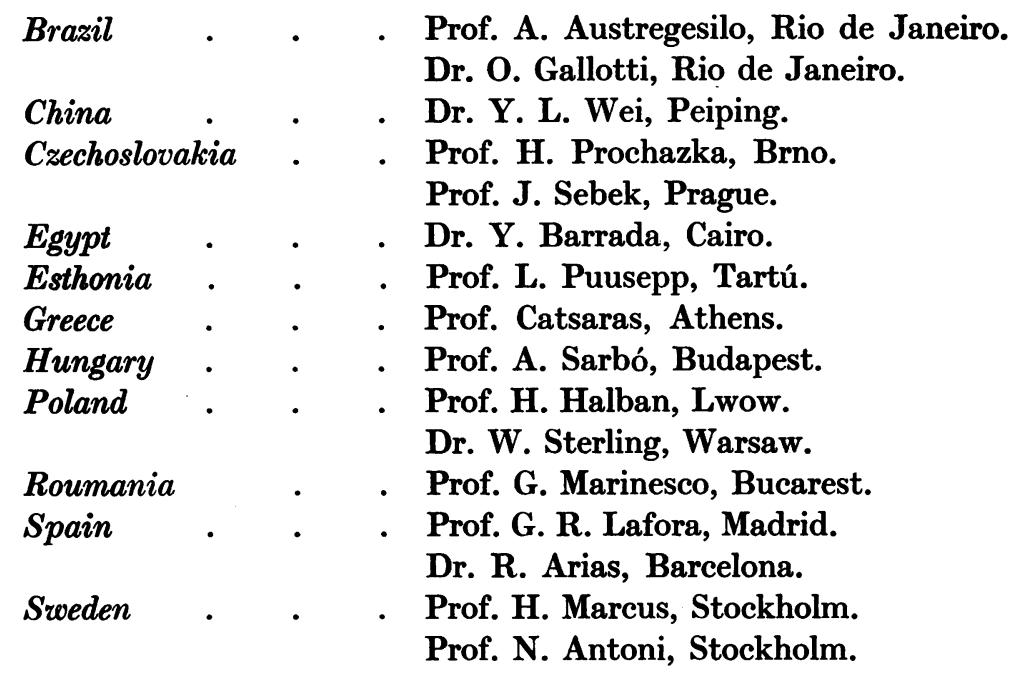

II. On Wednesday evening, September 6, a Reception of Delegates attending the Conference, and their Ladies, was held at the House of the Royal Society of Medicine. The Delegates were received by Mr. Warren Low, President of the Royal Society of Medicine, Dr. Risien Russell, President of the Neurological Section of the Society, and Dr. B. Sachs, President of the First International Neurological Congress, Berne, 1931. During the Reception an informal meeting of a number of Delegates took place, to arrange for a list of nominations for the officers of the Congress for 1935. This meeting was presided over by Dr. B. Sachs, and was attended by Drs. Brouwer, Dubois, Foerster, Holmes, Lhermitte, Marburg, Rossi and Riley.

III. On Thursday morning, September 7, the official Business Session of the Conference began, with Dr. B. Sachs in the Chair.

The minutes of the Meeting of the Programme-Executive Committee of the First International Neurological Congress, held in Berne, August 29-30, 1929, were read.

The Delegates then proceeded to nominate officers for the Second International Neurological Congress, London, 1935, as follows :

$$
\begin{array}{lll}
\text { Honorary President } & \text {. } & \text { Dr. B. Sachs. } \\
\text { President . } & \text {. } & \text { Sir Charles Sherrington. } \\
\text { Deputy President } & \text {. } & \text { Dr. Gordon Holmes. }
\end{array}
$$


Vice-Presidents :
Dr. Austregesilo (Brazil).
Dr. Marburg (Austria).
Dr. Balado (Argentine).
Dr. Moniz (Portugal).
Dr. Brouwer (Holland).
Dr. Monrad-Krohn (Norway).
Dr. Christiansen (Denmark).
Dr. Orzechowski (Poland).
Dr. Foerster (Germany).
Dr. Riley (United States).
Dr. Haskovec (Czechoslovakia).
Dr. Rossi (Italy).
Dr. Lafora (Spain).
Dr. Russel (Canada).
Dr. Ley (Belgium).
Dr. Schaffer (Hungary).

The Conference decided that Japan, Roumania and Russia are to be consulted as to their choice of a representative of their respective countries to act as Vice-President.

\begin{tabular}{|c|c|}
\hline Secretary-General & Dr. Kinnier Wilson. \\
\hline Assistant Secretaries & Dr. M. Critchley, Dr. E. A. Carmichael. \\
\hline Treasurer & Dr. A. Feiling. \\
\hline Editor of Transactions & - Dr. Gordon Holmes. \\
\hline Assistant Editors & $\begin{array}{l}\text { Drs. J. Lhermitte, V. M. Buscain } \\
\text { R. Arias, C. Dubois. }\end{array}$ \\
\hline
\end{tabular}

The Conference then proceeded to discuss plans for the meetings of the Congress of 1935. It was decided that the Congress should take place in London, and that the dates should be from Monday, July 29, to Friday, August 2, 1935.* It was further decided to adopt the same arrangement as was followed at the Berne Congress, viz., to devote Monday, Tuesday, Thursday, Friday to scientific sessions, reserving Wednesday for non-scientific activities.

It was also decided to select four subjects for discussion during the morning sessions, the afternoon sessions being devoted to miscellaneous papers, the number of afternoon sessions to be determined by the total number of papers offered and accepted.

After full discussion the following subjects were chosen for the morning sessions, viz. :

1. The Epilepsies-their Atiology, Pathogenesis and Treatment.

Chairmen : Profs. O. Marburg, O. Rossi.

2. The Physiology and Pathology of the Cerebrospinal Fluid.

Chairman: Prof. O. Foerster.

3. The Functions of the Frontal Lobe.

Chairman : Prof. H. Claude.

4. The Hypothalamus and the Central Representation of the Autonomic System.

Chairman : Prof. B. Brouwer.

* The date originally selected was August 5-9, but as this is inconvenient by reason of a public holiday, the British Officers of the Congress, after consultation with the delegates from the United States, have chosen July 29-August 2. 
In regard to the first of these, the Conference decided to devote two sessions to the subject, viz., a morning and an afternoon session on the same day, hence two Chairmen were selected.

The Conference came to the following decisions in regard to the programmes for the morning sessions :

(1) A maximum of five official rapporteurs for each subject, with the exception of The Epilepsies, for which the maximum is eight.

(2) Twenty minutes is the maximum time allowed each rapporteur.

(3) After the rapporteurs have given their communications, discussion will be thrown open by the Chairman, each person taking part in it being allowed five minutes for his remarks.

(4) Completed papers for the morning sessions to be in the hands of the Chairmen or the Programme Committee (vide infra) by March 1, 1935.

(5) Abstracts of each paper for the morning sessions to be submitted to the Programme Committee (vide infra) for incorporation in the published Congress Programme not later than March 1, 1935.

(6) Abstracts of contributions on the same morning subject to be furnished as soon as possible to the other rapporteurs on that subject, in order to prevent overlapping.

The Conference then proceeded to a discussion of the arrangements for the afternoon sessions, to be devoted to miscellaneous subjects, and came to the following decisions :

(1) The choice of Chairmen for the afternoon sessions will depend on the number of papers submitted and accepted and therefore on the number of sessions required. The Chairmen will be chosen (by the Programme Committee) from among the Vice-Presidents of the Congress, and the Chairmen may designate other distinguished members of the Congress for the same purpose.

(2) Not more than one contribution from any one member of the Congress will be allowed, but members may take part in any discussion, and any official rapporteur for any of the morning subjects may also present one other paper of a miscellaneous character.

(3) The Programme Committee will decide on its merits whether any particular contribution to the afternoon sessions is to be accepted or not.

(4) The maximum time for presentation of a miscellaneous paper is ten minutes.

(5) There will be open discussion of each afternoon paper, each person taking part in it being allowed five minutes for his remarks.

(6) As far as possible the Programme Committee will arrange that papers of a similar character will be grouped together in one or other of the afternoon sessions.

(7) Abstracts of all papers (or the papers themselves) submitted on 
miscellaneous subjects to be in the hands of the Programme Committee not later than March 1, 1935.

(8) In the case of papers presented in Italian or Spanish, the author must furnish an abstract of the same in either English, French, or German and submit it to the Programme Committee by the above-mentioned date.

The Programme Commitree was constituted by the Conference to consist of (1) The British Officers of the Congress and (2) the Chairmen of the morning discussions.

IV. On Thursday afternoon, September 7, the Conference continued its Business Session and proceeded to discuss the question of Membership of the Second International Neurological Congress.

1. Honorary Members were nominated as follows :

S. Ramon y Cajal (Madrid).

A. von Eiselsberg (Vienna).

Henry Head (London).

Wagner v. Jauregg (Vienna).

Fedor Krause (Berlin).

Pierre Marie (Paris).

G. Marinesco (Bucarest).
L. Minor (Moscorw).

J. P. Pavlov (Leningrad).

Friedrich Schultze (Bonn).

A. Souques (Paris).

E. Tanzi (Florence).

W. H. Welch (Baltimore).

C. Winkler (Utrecht).

2. Candidates for Active Membership may make application in one or other of two ways : either (i) through one of the National Committees, in which case their qualifications shall be examined by such National Committee, or (ii) by direct application to the Programme-Executive Committee through its Secretary, Dr. Kinnier Wilson, in which case their qualifications shall be examined by the Executive Committee. Membership cards for all members of the Congress shall be issued by the Secretary of the Congress and payments shall be made either through the National Committees or direct to the Treasurer of the Congress.

3. Associate Members shall consist of non-professional persons, men and women, interested in the Congress.

The question of financial support for the Congress was then discussed, and the following decisions reached :

1. Each National Committee is requested to be responsible for the following financial contributions to the support of the Congress for each of the two years 1934 and 1935, viz. :

(i) $\$ 100$ or its equivalent in Swiss francs-France, Germany, Great Britain, Italy, United States of America.

(ii) $\$ 50$ or its equivalent in Swiss francs-Austria, Holland, Switzerland.

(iii) $\$ 25$ or its equivalent in Swiss francs-Argentine, Brazil, Hungary, Poland, Roumania, Spain, U.S.S.R. 
(This arrangement is based on the numerical membership of the respective countries at the Berne Congress of 1931.)

2. The Conference expressed the unanimous opinion that while none of the National Committee of the countries mentioned in paragraph 1 above need consider themselves compelled to subscribe the specified amount they should not merely endeavour to do so but increase the amount if they are able to ; further, that the National Committees of countries not mentioned in paragraph 1 above should be requested to make such contributions as they can.

3. The same fee for Active Members as at Berne, 1931, was chosen, viz., the equivalent of 25 Swiss francs for each participant in the Congress.

4. The fee for Associate Members is one half of the fee for Active Members, viz., one half of the equivalent of 25 Swiss francs.

The question of the official languages of Congress was discussed at length. The decision was, that English, French, German, Italian, and Spanish are the official languages. Any member, however, who presents his communications in Italian or Spanish must previously forward to the Programme Committee an abstract of his paper in either English, French, or German (vide supra).

All arrangements for the accommodation of members of the Congress, and for publicity, were left in the hands of the British Organizing Committee.

Messrs. Thos. Cook and Son were appointed official Travel Agents for the Congress.

V. On Thursday evening, September 7, the Délegates and their Ladies were entertained to dinner at the Dorchester Hotel by the Neurological Section of the Royal Society of Medicine. The guests numbered 31, the hosts (ladies and gentlemen) 29.

S. A. KINNIER WILSON, Secretary-General.

14 Harley Street, London, W.1.

MATIONAL HOSPITAL, QUEEN SQUARE, MEDICAL SCHOOL.

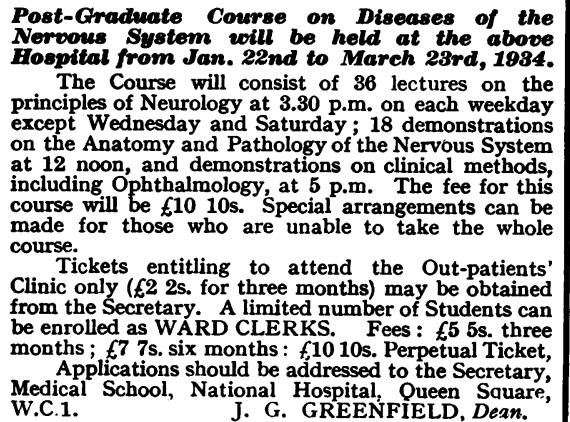

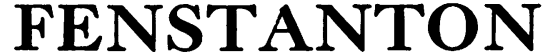

\section{GHRISTGHURGH ROAD STREATHAM HILL, S.W.2}

A Private Home for the Treatment of LADIES with Mental and Nervous Disorders. 12 acres of Grounds. Homelike surroundings, amusements and occupations.

Apply :

J. H. EARLS, M.D., Resident Physician

Telephone: TULSE HILL 7181 